Research Article

\title{
Effects of Synthetic Procedures and Postsynthesis Incubation pH on Size, Shape, and Antibacterial Activity of Copper (I) Oxide Nanoparticles
}

\author{
Vinh Tien Nguyen (iD) and Khanh Son Trinh \\ Faculty of Chemical and Food Technology, Ho Chi Minh City University of Technology and Education, 1 Vo Van Ngan Street, \\ Linh Chieu Ward, Thu Duc District, Ho Chi Minh City, Vietnam
}

Correspondence should be addressed to Khanh Son Trinh; sontk@hcmute.edu.vn

Received 26 February 2020; Revised 6 April 2020; Accepted 18 April 2020; Published 8 June 2020

Academic Editor: Nenad Ignjatović

Copyright ( 2020 Vinh Tien Nguyen and Khanh Son Trinh. This is an open access article distributed under the Creative Commons Attribution License, which permits unrestricted use, distribution, and reproduction in any medium, provided the original work is properly cited.

Copper (I) oxide nanoparticles $\left(\mathrm{Cu}_{2} \mathrm{O} N P\right.$ ) were synthesized by reducing $\mathrm{CuSO}_{4}$ with glucose in the presence of polyvinyl alcohol as a capping agent. We used three different synthetic procedures with a fast reaction (procedure $1 p$ ), a fast-then-slow reaction (procedure $2 p$ ), and a slow-then-fast reaction (procedure $3 p$ ). The reaction rates were controlled by changing the temperature and the speed of adding reagents. The synthesized $\mathrm{Cu}_{2} \mathrm{O} \mathrm{NP}$ were subsequently incubated for $24 \mathrm{~h}$ in a pH 6 solution $\left(\mathrm{Cu}_{2} \mathrm{O} \mathrm{NP} 6\right)$ or a $\mathrm{pH} 8$ solution $\left(\mathrm{Cu}_{2} \mathrm{O} \mathrm{NP} 8\right)$ at $5^{\circ} \mathrm{C}$. XRD and SEM images analysis revealed that the $1 p$ procedure produced smaller NP, while the $2 p$ procedure produced larger but more uniform NP. The $3 p$ procedure produced the largest NP with a higher size variation. The 24-hour acidic postsynthesis incubation resulted in an etching effect, which reduced the size and size variation of $\mathrm{Cu}_{2} \mathrm{O} \mathrm{NP}$. To evaluate the antibacterial activity, E. coli suspensions were mixed with the obtained $\mathrm{Cu}_{2} \mathrm{O} \mathrm{NP}(32$, 96, or 160 ppm) for different time intervals $\left(1\right.$ or $24 \mathrm{~h}$ ) and then grown on Petri dishes at $37^{\circ} \mathrm{C}$ for $24 \mathrm{~h}$. Higher doses, smaller sizes of $\mathrm{Cu}_{2} \mathrm{O} \mathrm{NP}$, and longer contact times with the bacterial suspension resulted in higher inactivation efficiencies. $\mathrm{Cu}_{2} \mathrm{O}$ NP6 showed higher antibacterial effects at low doses, possibly due to the etching effect and the positive surface charge. Increasing the $\mathrm{Cu}_{2} \mathrm{O}$ doses from 32 to 96 and 160 ppm noticeably increased the antibacterial effect of the $\mathrm{Cu}_{2} \mathrm{O} \mathrm{NP} 8$, but not significantly for $\mathrm{Cu}_{2} \mathrm{O}$ NP6. We suggested that the $\mathrm{Cu}_{2} \mathrm{O}$ NP6 suffered from agglomeration at high doses due to their high surface activity and low surface charges.

\section{Introduction}

One of the main problems with conventional antibiotics is that their extensive and prolonged use results in the resistance of various infectious bacterial strains against them [1]. Antibacterial nanomaterials have emerged with many advantages, including high effectiveness, robustness, variety, and low doses [2]. Metallic-based antibacterial nanomaterials are mostly made from transition metals such as silver, zinc, gold, and copper [3]. Silver in recent decades has proved to be a highly effective biocidal agent, but with two major drawbacks: high price and lack of a proper requisition channel resulting in high toxicity [4]. Copper-based nanomaterials can overcome these problems because they are abundant, have low-cost, and can be expelled out of the body [5]. Among copper compounds, copper oxides have emerged as excellent nanomaterials for antibacterial applications because of their high antibacterial effectiveness and storage stability [6]. Cuprous oxide $\mathrm{Cu}_{2} \mathrm{O}$ was found to be more effective than cupric oxide $\mathrm{CuO}$ in antibacterial activity $[7,8] . \mathrm{Cu}_{2} \mathrm{O}$ has shown biocidal effects against a wide range of microorganisms, including pathogenic bacteria [9-11], fungi [12, 13], and viruses [11].

Besides complicated methods or those requiring special equipment, such as physical [14], electrochemical [15], photochemical [16], and sonochemical [17] techniques, the wet chemical approach is simpler and easier to control and scale up the $\mathrm{Cu}_{2} \mathrm{O}$ nanoparticles (NP) production [18]. The most common precursors for $\mathrm{Cu}_{2} \mathrm{O}$ NP synthesis are copper (II) salts $\left(\mathrm{CuSO}_{4}, \mathrm{CuCl}_{2}\right.$, and $\mathrm{Cu}\left(\mathrm{NO}_{3}\right)_{2}$ or $\left.\left(\mathrm{CH}_{3} \mathrm{COO}\right)_{2} \mathrm{Cu}\right)$, and the common reducing agents are sodium borohydride, hydrazine, 
1,2-hexadecanediol, glucose, ascorbic acid, $\mathrm{CO}$, or borane compounds [19]. Among these reducing agents, glucose is the cheapest, environmentally green, and highly selective in producing $\mathrm{Cu}_{2} \mathrm{O}$ [20]. The synthesis of $\mathrm{Cu}_{2} \mathrm{O}$ NP usually requires one or more capping agents to control their shapes and sizes and prevent their agglomeration [21].

The classic LaMer mechanism of NP formation includes nucleation and growth stages, each of which can affect the size of NP. A fast reaction induced by high temperature and quick allat-once mixing of reagents produces a burst of small nuclei in the nucleation stage and subsequent growth of these nuclei. Such fast one-step procedures usually produce small NP with a wide size distribution [22]. The size distribution of NP products can be narrower if the reaction is conducted using the extended LaMer mechanism: quickly mixing a portion of the reagents at a high temperature to produce a high amount of small nuclei first, and then slowly adding the remaining reagents at low temperature for uniform growth of the produced nuclei [23]. If the temperature is raised after the NP are formed, Ostwald ripening happens, where larger particles continue to grow with the material dissolved from the smaller particles. As a result, in the short term, the large particles become larger and the small particles become smaller, thus widening the size distribution of the NP [24]. In this study, we tested these three concepts on the synthesis of $\mathrm{Cu}_{2} \mathrm{O} N \mathrm{NP}$ using glucose as the reducing agent, copper sulfate as the precursor, and polyvinyl alcohol (PVA) as the capping agent.

Furthermore, the size of $\mathrm{Cu}_{2} \mathrm{O}$ NP can also be affected by the environment $\mathrm{pH}$ after their synthesis. It is known that $\mathrm{Cu}_{2} \mathrm{O}$ is stable in alkaline solutions and disproportionates in acidic solutions [25]. Therefore, incubating $\mathrm{Cu}_{2} \mathrm{O}$ in a slightly acidic solution can etch the surface of $\mathrm{Cu}_{2} \mathrm{O}$, thus affecting its size, morphology, and chemical and microbiological activities.

To the best of our knowledge, although $\mathrm{Cu}_{2} \mathrm{O}$ NP have been intensively investigated, there is still no research on using the postsynthesis disproportionation of $\mathrm{Cu}_{2} \mathrm{O}$ as a technique to modify the surface and the antibacterial properties of $\mathrm{Cu}_{2} \mathrm{O}$ NP. In this study, after preparing $\mathrm{Cu}_{2} \mathrm{O}$ $\mathrm{NP}$ by the three aforementioned procedures, we incubated them in two buffers with $\mathrm{pH}$ of 6.0 and 8.0 and evaluated how these treatments affected the size distribution, the shapes, and the antibacterial efficiencies of the $\mathrm{Cu}_{2} \mathrm{O}$ NP.

\section{Materials and Methods}

2.1. Materials. Escherichia coli VTCC-B-482 strain was purchased from the Microorganisms Bank of the Institute of Microbiology and Biotechnology, Hanoi National University. Glucose, $\mathrm{CuSO}_{4} .5 \mathrm{H}_{2} \mathrm{O}, \mathrm{NaOH}, \mathrm{PVA}$, and $\mathrm{H}_{2} \mathrm{SO}_{4}$ were purchased from Xilong Scientific Ltd. (China). All the chemicals were of analytical grade and used without further purification.

2.2. Procedures for Copper (I) Oxide Synthesis. In this study, we used three procedures modified from a published method to synthesize $\mathrm{Cu}_{2} \mathrm{O}$ NP [26]. All the three procedures used the same two solutions: $50 \mathrm{~mL}$ of solution A (1.6 M PVA and $1 \mathrm{M}$ glucose) and $50 \mathrm{~mL}$ of solution $\mathrm{B}$ (1.6 M PVA and $0.01 \mathrm{M}$ $\mathrm{CuSO}_{4}$ ). The solutions were always stirred continuously during the reaction.
The first procedure was conducted in one step at a high temperature. Both solutions A and B were heated and kept at $60^{\circ} \mathrm{C}$ for $15 \mathrm{~min}$ under continuous stirring. The temperature of $60^{\circ} \mathrm{C}$ was selected to avoid browning reactions of glucose at higher temperatures. Solution $\mathrm{B}$ was then quickly added to solution A. To trigger the reduction of copper (II) ions to $\mathrm{Cu}_{2} \mathrm{O}$ by glucose, the mixture $\mathrm{pH}$ was adjusted to 10 by using a $1 \mathrm{M}$ $\mathrm{NaOH}$ solution. After $30 \mathrm{~min}$ of reaction, the mixture was cooled to room temperature, adjusted to $\mathrm{pH} 6.0$ or 8.0, and stored at $5^{\circ} \mathrm{C}$ in a refrigerator for one day $(1 p 6$ and $1 p 8$ procedures, correspondingly).

The second procedure for $\mathrm{Cu}_{2} \mathrm{O}$ synthesis was conducted in two steps. The first step was quick mixing of the reagents at high temperature and the second step was slow mixing of the reagents at low temperature. To do this, solution $\mathrm{B}$ was divided into two halves. The first half was heated to $60^{\circ} \mathrm{C}$ and quickly added to solution A already at $60^{\circ} \mathrm{C}$. The $\mathrm{pH}$ was then adjusted to 10 by adding the $1 \mathrm{M} \mathrm{NaOH}$ solution. After $30 \mathrm{~min}$ of reaction, the mixture was cooled to room temperature and the second half of $\mathrm{B}$ was slowly and dropwise added from a burette for $30 \mathrm{~min}$. During this process, the $\mathrm{pH}$ was continuously kept at 10 by adding the $1 \mathrm{M} \mathrm{NaOH}$ solution. The mixture was left reacting for $24 \mathrm{~h}$, then adjusted to $\mathrm{pH} 6.0$ or 8.0 , and stored at $5^{\circ} \mathrm{C}$ for one day $(2 p 6$ and $2 p 8$ procedures, correspondingly).

The third procedure for $\mathrm{Cu}_{2} \mathrm{O}$ synthesis was conducted in one step at a low temperature with a subsequent Ostwald ripening of the NP at high temperature. Solutions A and B were mixed at once at room temperature, and the mixture was adjusted to $\mathrm{pH} 10$. After $1 \mathrm{~h}$ of reaction, the mixture was heated to $80^{\circ} \mathrm{C}$ in a water bath to complete the reduction reaction and speed up the Ostwald ripening. The concentration of the remaining glucose was low and did not induce browning reactions even at $80^{\circ} \mathrm{C}$. After $30 \mathrm{~min}$, the $\mathrm{pH}$ was adjusted to 6.0 or 8.0 and then stored at $5^{\circ} \mathrm{C}$ for one day ( $3 p 6$ and $3 p 8$ procedures, correspondingly).

To prepare the $\mathrm{Cu}_{2} \mathrm{O}$ NP samples for structural and antibacterial characterization, the solid in the reaction mixture was collected by centrifugation at $10,000 \mathrm{rpm}$ for $20 \mathrm{~min}$ and washed with distilled water for 3 times. After that, the solid was dispersed in absolute ethanol under ultrasonication for $1 \mathrm{~h}$. The dispersion was then vacuumdried at $40^{\circ} \mathrm{C}$ for $8 \mathrm{~h}$ and stored for further characterization. $\mathrm{Cu}_{2} \mathrm{O}$ NP samples incubated at $\mathrm{pH} 6$ and $\mathrm{pH} 8$ are designated as $\mathrm{Cu}_{2} \mathrm{O}$ NP6 and NP8, respectively.

\subsection{Morphology, Size, and Crystal Structure of $\mathrm{Cu}_{2} \mathrm{O} N P$.} The morphology and the size of the $\mathrm{Cu}_{2} \mathrm{O}$ particles were observed using a Field-Emission Scanning Electron Microscope (FE-SEM) S-4800 (Hitachi, Japan). The sizes of 400 particles were determined using ImageJ software (version $\mathrm{K}$ $1.45)$ on the FE-SEM images. The type of crystal structure and the average crystallite size of the $\mathrm{Cu}_{2} \mathrm{O} \mathrm{NP}$ were determined from XRD patterns recorded on an X-ray Diffractometer (D8 Advanced, Bruker, Germany) at $25^{\circ} \mathrm{C}$. The 2-theta angles were scanned from $10^{\circ}$ to $80^{\circ}$, with $\lambda=0.15418 \mathrm{~nm}$. The average size of $\mathrm{Cu}_{2} \mathrm{O} \mathrm{NP}$ crystallites was calculated using the Scherrer formula [27]: 


$$
d=\frac{K \cdot \lambda}{B \cdot \cos \theta}
$$

where $d$ is the average size of the crystallites (nm); $K$ is the Scherrer constant $(K=0.94)$ assuming spherical shape of the particles [28]; $\lambda$ is the X-ray wavelength $=1.54178 \AA$ for $\mathrm{Cu} K \alpha$; and $B$ is the full width at half maximum of the highest peak (rad).

2.4. Antibacterial Activity of $\mathrm{Cu}_{2} \mathrm{O} N P$. The antibacterial activity of the synthesized $\mathrm{Cu}_{2} \mathrm{O} \mathrm{NP}$ was evaluated on $E$. coli by mixing the NP with the bacterial suspensions at different $\mathrm{Cu}_{2} \mathrm{O}$ contents and determining the viability of the bacteria by the colony counting method after incubation on Petri dishes [29]. Different amounts of the synthesized $\mathrm{Cu}_{2} \mathrm{O} \mathrm{NP}$ were added to $1 \%$ peptone solutions containing E. coli of about $100 \mathrm{CFU} / \mathrm{mL}$ to reach the desired copper (I) content (32,96, and $160 \mathrm{ppm})$. After 1 or $24 \mathrm{~h}$ of shaking at $180 \mathrm{rpm}$ and at room temperature, the mixture was added to a Nutrient Agar medium at $45^{\circ} \mathrm{C}$. The mixture was then thoroughly shaken and then poured into Petri dishes. After incubating the Petri dishes at $37^{\circ} \mathrm{C}$ for $24 \mathrm{~h}$, the number of colonies in each Petri dish was counted. The same procedure was carried out with the negative control experiment ( $0 \%$ growth inhibition), where $\mathrm{Cu}_{2} \mathrm{O}$ was not added to the bacterial suspension. To compare the antibacterial activity of the $\mathrm{Cu}_{2} \mathrm{O} N P$ with the $\mathrm{Cu}^{2+}$ ions, we carried out the same procedure above with $\mathrm{Cu}_{2} \mathrm{O}$ replaced by the solution $\mathrm{B}\left(\mathrm{CuSO}_{4}\right.$ and $\left.\mathrm{PVA}\right)$ containing an equivalent copper amount.
The inactivation efficiency was calculated using the following formula:

$$
H=\frac{A_{1}-A_{2}}{A_{1}} \times 100,
$$

where $H$ is the inactivation efficiency (\%); $A_{1}$ is the average number of colonies on the Petri dish in the negative control experiment; and $A_{2}$ is the average number of colonies on the Petri dish after contacting the bacterial suspension with $\mathrm{Cu}_{2} \mathrm{O}$.

All the antibacterial experiments were replicated 3 times.

The statistical analyses of all size distributions and inactivation efficiencies of $\mathrm{Cu}_{2} \mathrm{O} \mathrm{NP}$ were calculated at $95 \%$ confidence level using $\mathrm{R}$ software package.

\section{Results and Discussion}

3.1. Synthesis Reactions and XRD Characterization of the Product. The reaction between a reducing sugar and copper (II) complex ions in an alkaline solution to form copper (I) oxide is the basis of the well-known Fehling and Benedict reactions. In aqueous solutions with high $\mathrm{pH}, \alpha$-glucose rings are opened and partially mutarotated into $\beta$-glucose through a chain configuration equation (3). The carbonyl group $-\mathrm{CH}=\mathrm{O}$ in this chain configuration of glucose can reduce copper ions to $\mathrm{Cu}_{2} \mathrm{O}$ equation (4).

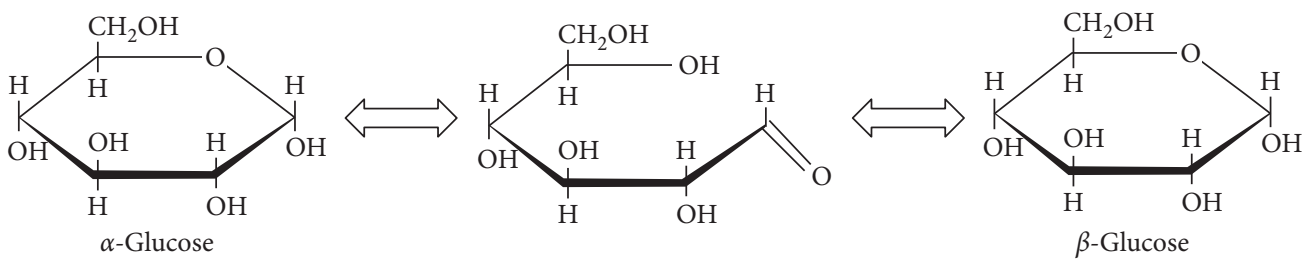



Under certain reaction conditions, the carbonyl groups can further reduce $\mathrm{Cu}_{2} \mathrm{O}$ to metallic $\mathrm{Cu}[26,30,31]$.

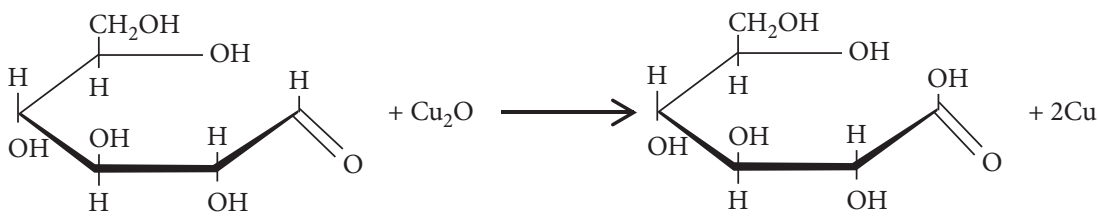


Therefore, to determine the identity and the phase composition (if a mixture was formed) and to evaluate the crystallites size and shape of the obtained samples, their XRD patterns were recorded and are shown in Figure 1.

The strong and sharp peaks in the XRD patterns of all six samples show that the obtained materials were crystalline. The JCPDS Card No. 05-0667 of $\mathrm{Cu}_{2} \mathrm{O}$ matches very well with the $2 \theta$ values of the peaks of $29.78^{\circ}, 36.64^{\circ}, 42.54^{\circ}, 61.72^{\circ}$, and $73.93^{\circ}$, which correspond to (110), (111), (200), (220), and (311) face-centered cubic (fcc) indices, respectively [32].

The absence of other peaks in the XRD patterns indicates that the obtained samples were not contaminated with other copper compounds $\left(\mathrm{Cu}, \mathrm{CuO}\right.$, or $\left.\mathrm{Cu}(\mathrm{OH})_{2}\right)$. This result is different from that of a study reporting the formation of solely metallic $\mathrm{Cu}$ (with $2 \theta$ of $43.3^{\circ}, 50.4^{\circ}$, and $74.1^{\circ}$ ) from the reaction of copper acetate and glucose in the presence of polyvinylpyrrolidone as the protecting agent at $\mathrm{pH} 10$ [26]. This difference indicates that the nature of the copper precursor and/or the protecting polymer can determine the product identity in this Fehling type of reaction.

From the average full widths at half maximum of the peaks, the average crystallite sizes of $\mathrm{Cu}_{2} \mathrm{O}$ NP were calculated using the Scherrer equation and are shown in Table 1.

The results in Table 1 demonstrate that $\mathrm{Cu}_{2} \mathrm{O}$ NP produced by a fast reaction (high temperature and quick mixing of reagents in procedure 1) yielded NP crystallites smaller than those produced by a slow reaction (procedures 2 and 3 ).

The relative intensities of (111) and (200) peaks can give some information about the shape of the $\mathrm{Cu}_{2} \mathrm{O}$ nanocrystallites. A recent study found a noticeable relationship between the morphology of the $\mathrm{Cu}_{2} \mathrm{O} N \mathrm{NP}$ and the relative intensities of the (200) and (111) peaks in the XRD patterns: perfect octahedral $\mathrm{Cu}_{2} \mathrm{O}$ nanocrystals have no (200) peak, while the cubic nanocrystals have a (200) peak higher than that of (111) [33]. When the shape of $\mathrm{Cu}_{2} \mathrm{O}$ nanocrystals evolves from octahedral through (100)-truncated octahedral to cubic, the ratio of (200): (111) peak intensities increases from 0 to nearly 2 . In our study, all the samples had the (200): (111) ratios in the range 0.31-0.37, indicating the (100)-truncated octahedral morphology. Table 1 also shows that the $\mathrm{Cu}_{2} \mathrm{O}$ NP6 had higher ratios of (200): (111) peak intensities, than the corresponding $\mathrm{Cu}_{2} \mathrm{O}$ NP8. This result demonstrates that the acidic incubation has an etching or truncating effect on the (100) surface of the $\mathrm{Cu}_{2} \mathrm{O}$ NP.

\subsection{Morphology and Size by SEM Characterization.} FE-SEM micrographs (Figure 2) of the synthesized $\mathrm{Cu}_{2} \mathrm{O}$ materials were recorded to determine the particle sizes and morphology. In the scale of $5 \mu \mathrm{m}$, the $\mathrm{Cu}_{2} \mathrm{O}$ particles prepared by the three procedures and stored at $\mathrm{pH}$ values of 6 and 8 had relatively uniform shapes and sizes.

The sizes of at least 400 particles for each sample were determined using the Image software on the FE-SEM images. The mean, the standard deviation, and the coefficient of variation of these particle sizes are presented in Table 2.

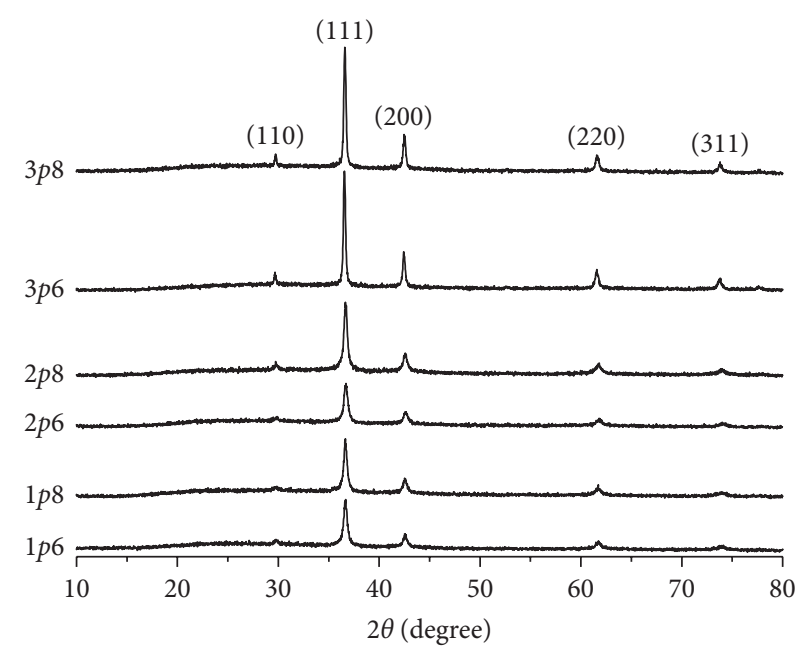

FIGURE 1: XRD patterns of $\mathrm{Cu}_{2} \mathrm{O}$ powder samples prepared by different procedures.

TABLE 1: Average crystallite sizes of $\mathrm{Cu}_{2} \mathrm{O}$ NP prepared by different procedures.

\begin{tabular}{lcccccc}
\hline Procedure & $1 p 6$ & $1 p 8$ & $2 p 6$ & $2 p 8$ & $3 p 6$ & $3 p 8$ \\
\hline $\begin{array}{l}\text { Average crystallites size } \\
(\mathrm{nm})\end{array}$ & 12.6 & 12.0 & 12.3 & 14.3 & 26.1 & 23.7 \\
$\begin{array}{l}\text { Ratio of (200): (111) } \\
\text { peak intensities }\end{array}$ & 0.346 & 0.339 & 0.368 & 0.315 & 0.316 & 0.311 \\
\hline
\end{tabular}

The sizes of most $\mathrm{Cu}_{2} \mathrm{O}$ particles were in the range of 200-340 nm. In a similar study, where $\mathrm{CuCl}_{2}$ was reduced by glucose in alkaline medium at $75^{\circ} \mathrm{C}$, the sizes of $\mathrm{Cu}_{2} \mathrm{O}$ particles were approximately $2-3 \mu \mathrm{m}$ [20]. The $\mathrm{Cu}_{2} \mathrm{O}$ particle size in our study was about 10 times lower due to the use of PVA as a capping agent. This capping polymer forms a protective layer around the $\mathrm{Cu}_{2} \mathrm{O} \mathrm{NP}$ during the synthesis and thus prevents them from growing further [21].

Particles in sample $1 p 6$ had significantly smaller sizes, while those in sample $3 \mathrm{p} 8$ had significantly larger sizes, compared to the other samples. This pattern in particle sizes is consistent with the results obtained above by XRD analysis. It should be noted that the sizes in the FE-SEM analysis are higher than those in the XRD calculations because the XRD-based sizes are of the small crystallites that agglomerated into particles observed in the FE-SEM images [34].

A comparison of the standard deviations of $\mathrm{Cu}_{2} \mathrm{O} N P$ produced by the three procedures shows that the procedure with fast nucleation and subsequent slow growth ( $2 p 6$ and $2 p 8)$ yielded particles with more uniform sizes (smaller standard deviations and coefficients of variation). This result is in accordance with LaMer theory and the practice of size-controlled NP synthesis [22]. In the first step at high temperature and quick mixing of reagents, a burst formation of small nuclei of $\mathrm{Cu}_{2} \mathrm{O}$ occurred because of the high reaction rate between $\mathrm{Cu}^{2+}$ and glucose. In the second step at low temperature and slow dropwise adding of the solution $\mathrm{B}$, new $\mathrm{Cu}_{2} \mathrm{O}$ monomers were formed slowly, diffused to the surface of the above-mentioned nuclei, and deposited uniformly $[22,35]$. When the $\mathrm{Cu}_{2} \mathrm{O} \mathrm{NP}$ 


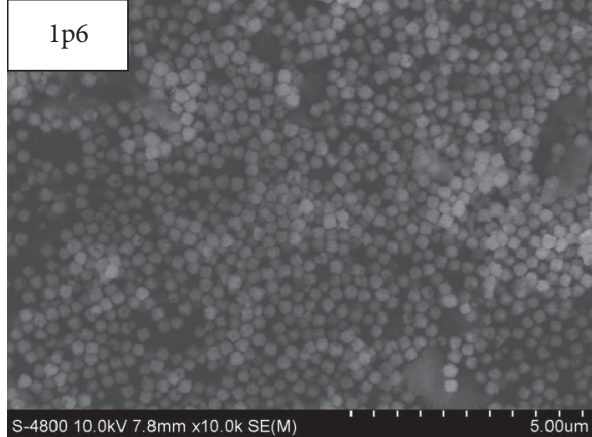

(a)



(c)



(e)

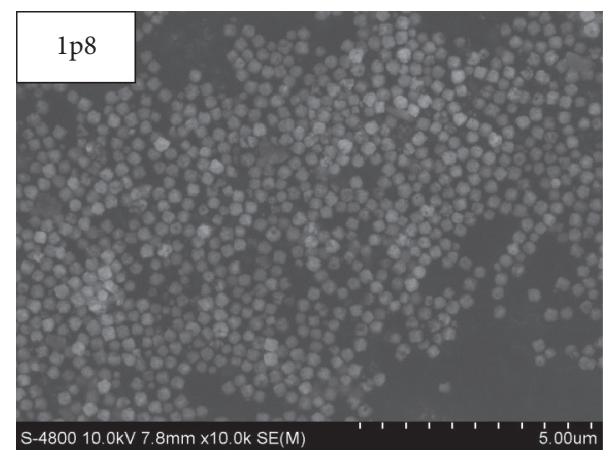

(b)

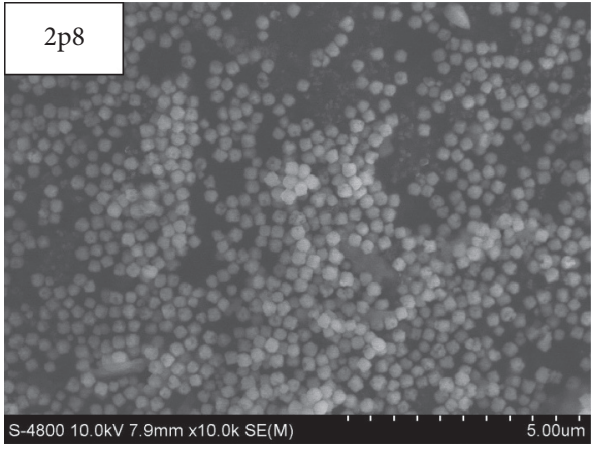

(d)

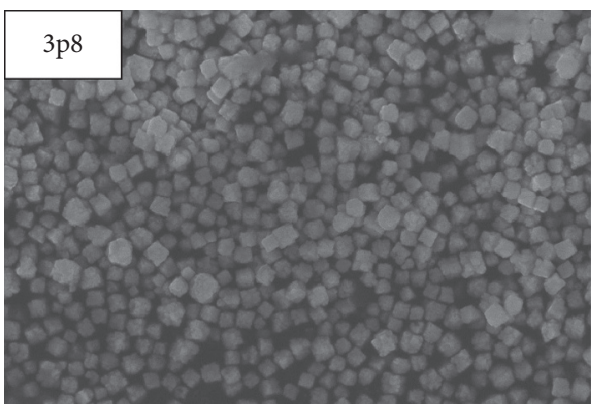

(f)

Figure 2: FE-SEM micrographs of $\mathrm{Cu}_{2} \mathrm{O}$ samples at $5 \mu \mathrm{m}$ scale (10,000x magnification): (a) $1 p 6$, (b) $1 p 8$, (c) $2 p 6$, (d) $2 p 8$, (e) $3 p 6$, and (f) $3 p 8$.

TABle 2: Particle sizes (mean \pm standard deviation) of the $\mathrm{Cu}_{2} \mathrm{O}$ samples.

\begin{tabular}{lcccccc}
\hline Sample & $1 p 6$ & $1 p 8$ & $2 p 6$ & $2 p 8$ & $3 p 6$ & $3 p 8$ \\
\hline Particle size $(\mathrm{nm})$ & $222 \pm 13^{\mathrm{a}}$ & $240 \pm 21^{\mathrm{ab}}$ & $240 \pm 3^{\mathrm{ab}}$ & $248 \pm 10^{\mathrm{ab}}$ & $263 \pm 7^{\mathrm{b}}$ & $310 \pm 33^{\mathrm{c}}$ \\
Coefficient of variation (\%) & 5.9 & 8.9 & 1.3 & 4.0 & 2.7 & 10.6 \\
\hline
\end{tabular}

Means with different superscript letters are significantly different $(p<0.05)$.

were aged at $80^{\circ} \mathrm{C}$ in procedure 3 , Oswald ripening happened, resulting in the dissolution of smaller particles and the continued growth of larger ones [24]. As a result, the $\mathrm{Cu}_{2} \mathrm{O} N P$ in the $3 p$ procedures were significantly larger.

An interesting result from Table 2 is that the $\mathrm{Cu}_{2} \mathrm{O}$ NP particles incubated in acidic solutions $(\mathrm{pH}=6)$ tended to be smaller than those incubated in basic solutions $(\mathrm{pH}=8)$. This is possibly because $\mathrm{Cu}_{2} \mathrm{O}$ is stable only in an alkaline medium. In mildly acidic medium, $\mathrm{Cu}_{2} \mathrm{O}$ disproportionates into $\mathrm{Cu}$ and $\mathrm{Cu}^{2+}$ according to reaction (6) below, resulting in an "etching" effect that reduced the $\mathrm{Cu}_{2} \mathrm{O}$ particle size:

$$
\mathrm{Cu}_{2} \mathrm{O}(\mathrm{s})+2 \mathrm{H}^{+}(\mathrm{aq}) \longrightarrow \mathrm{Cu}^{2+}(\mathrm{aq})+\mathrm{Cu}(\mathrm{s})+\mathrm{H}_{2} \mathrm{O}(\mathrm{l}) \text {. }
$$

Table 2 also shows that $\mathrm{Cu}_{2} \mathrm{O}$ NP incubated at $\mathrm{pH} 6$ has smaller standard deviations in size than those incubated at $\mathrm{pH}$ 8. This means that acidic incubation yielded more uniform particles because the acidic etching attacked more on $\mathrm{Cu}_{2} \mathrm{O}$ particles with a larger surface.

The etching effect of acidic incubation can be observed in the holes on the surface of $\mathrm{Cu}_{2} \mathrm{O} \mathrm{NP}$ (white arrows in Figure 3). This effect also existed in $\mathrm{Cu}_{2} \mathrm{O}$ NP incubated at $\mathrm{pH} 8$, but to a lesser extent. This means that $\mathrm{Cu}_{2} \mathrm{O}$ NP also 


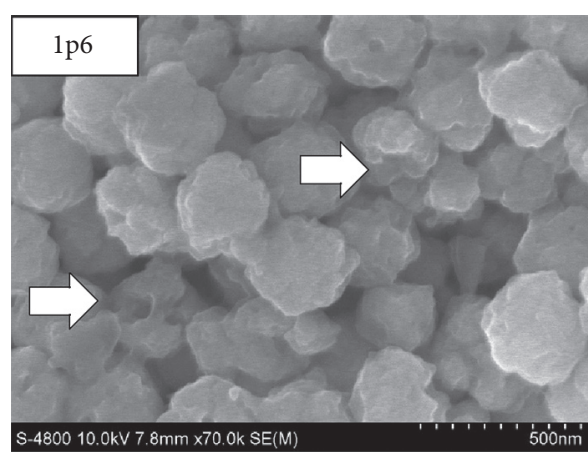

(a)



(c)

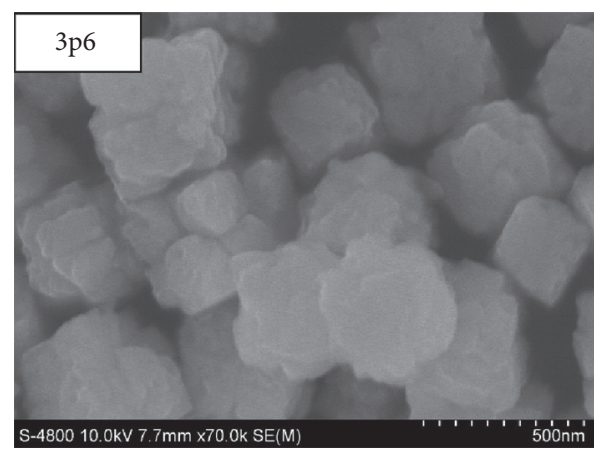

(e)



(b)

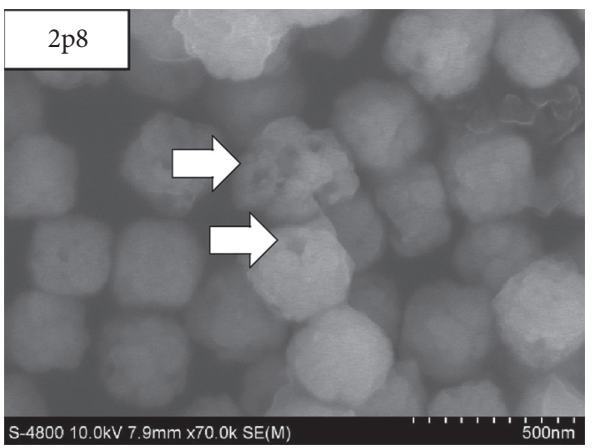

(d)

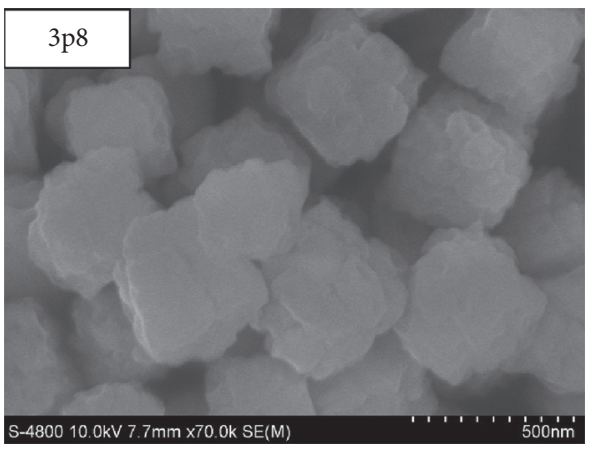

(f)

Figure 3: FE-SEM micrographs of $\mathrm{Cu}_{2} \mathrm{O}$ samples at $500 \mathrm{~nm}$ scale (70,000x magnification): (a) 1p6, (b) $1 p 8$, (c) 2p6, (d) $2 p 8$, (e) $3 p 6$, and (f) $3 p 8$.

disproportionated in slightly basic media. It is well known that this type of defects on the surface of solids enhances their catalytic activity in chemical reactions [36, 37]. The results of acidic incubation on the sizes and size distribution imply a way of controlled surface modification to produce uniform $\mathrm{Cu}_{2} \mathrm{O} \mathrm{NP}$ with high surface areas and catalytic potentials.

The morphology of $\mathrm{Cu}_{2} \mathrm{O}$ NP can be observed through FE-SEM images at 70,000x magnification (Figure 3). The shapes of $\mathrm{Cu}_{2} \mathrm{O}$ NP synthesized by procedures 1 and 2 are close to spheres, while that of NP synthesized by procedure 3 is close to octahedral or cubes. This interesting result indicates that changing the speed of the reaction stages can alter the shape of the produced NP. A slow nucleation step followed by a fast growth step seems to yield octahedral $\mathrm{Cu}_{2} \mathrm{O}$ crystals, while a fast nucleation step followed by a slow growing step produced spherical $\mathrm{Cu}_{2} \mathrm{O}$ crystals [38].
3.3. Antibacterial Effects of $\mathrm{Cu}_{2} \mathrm{ONP}$ on E. coli. Copper metal and its oxides are well known for their antifungal and antibacterial activities [39]. Figure 4 shows the inactivation percentage of $E$. coli after treating the bacterial suspension with the synthesized $\mathrm{Cu}_{2} \mathrm{O} \mathrm{NP}(32,96$, and 160 ppm of copper (I)) for $1 \mathrm{~h}$ (A and B) or $24 \mathrm{~h}$ (C and D). In all tested conditions, $\mathrm{Cu}_{2} \mathrm{O} \mathrm{NP}$ showed significantly higher inactivation efficiency compared to $\mathrm{CuSO}_{4}$. This is expectable, because previous studies have shown that $\mathrm{Cu}_{2} \mathrm{O}$ is more effective than $\mathrm{CuO}[7,8,40]$ and $\mathrm{CuO}$ is more effective than $\mathrm{Cu}^{2+}$ ions in inhibiting bacterial growth [6]. Although copper ions are toxic to bacterial cells, the lipophilic cell membranes are good barriers to them. On the other hand, solid $\mathrm{CuO}$ or $\mathrm{Cu}_{2} \mathrm{O}$ NP can stick to and penetrate the cell membranes and then release toxic copper ions inside the acidic lysosomes, like "Trojanhorse carriers" [41]. 




(a)

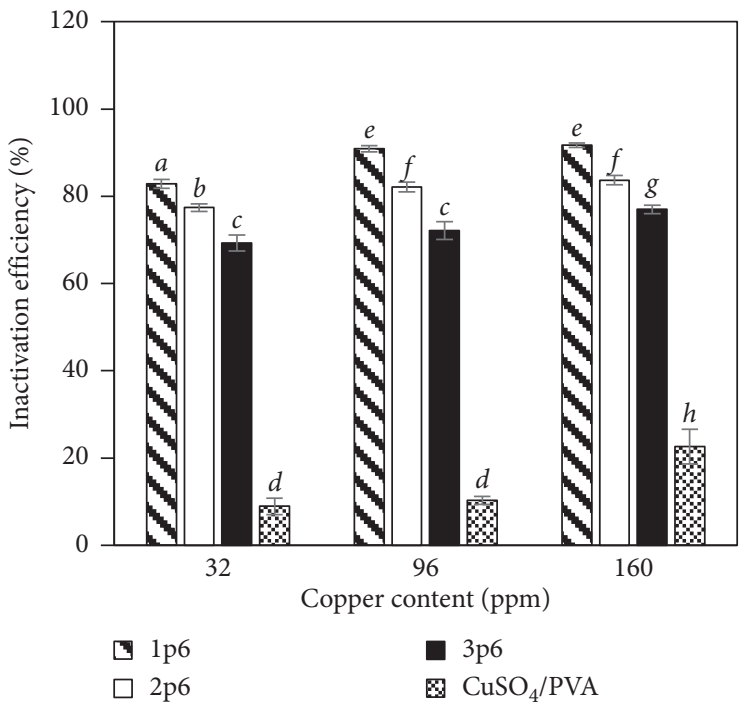

(c)

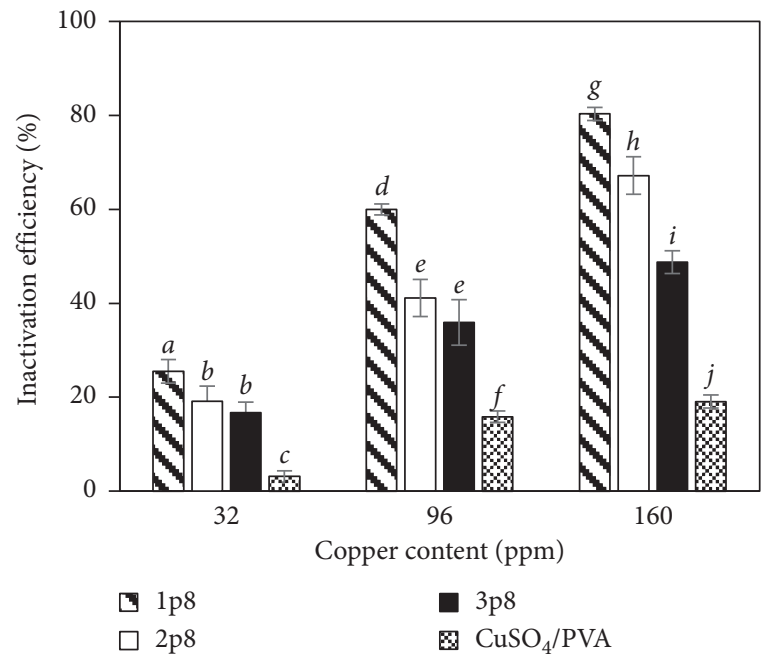

(b)



(d)

Figure 4: Inactivation efficiencies of $\mathrm{Cu}_{2} \mathrm{O}$ NP incubated at $\mathrm{pH} 6$ and $\mathrm{pH} 8$ after $1 \mathrm{~h}$ and $24 \mathrm{~h}$ of contact with E. coli suspension ((a) pH6, $1 \mathrm{~h}$; (b) $\mathrm{pH} 8,1 \mathrm{~h}$; (c) pH6, 24 h; (d) pH8, 24h). Different letters on the bars in the graph demonstrate significantly different inactivation efficiencies $(p<0.05)$.

A literature survey showed that the main mechanism of the antibacterial effect of $\mathrm{Cu}_{2} \mathrm{O} N P$ is direct contact killing and the subsequent complex formation between copper (I) ions with the peptides in the cell membranes [7]. This mechanism explains the high inactivation efficiencies of $\mathrm{Cu}_{2} \mathrm{O}$ NP with higher doses of the copper agents $\left(\mathrm{Cu}_{2} \mathrm{O}\right.$ and $\mathrm{CuSO}_{4}$ ) and longer contact times ( $24 \mathrm{~h}$ compared to $1 \mathrm{~h}$ ) with the bacterial suspension. This result is obvious because more $\mathrm{Cu}_{2} \mathrm{O} \mathrm{NP}$ present in the bacterial suspension and longer treatment time would increase the number of collisions and contacts between them and lead to higher antibacterial effects.

Figure 4 also shows that different procedures for $\mathrm{Cu}_{2} \mathrm{O}$ NP synthesis resulted in significantly different inactivation efficiencies $(p<0.05)$. The decreasing order of antibacterial activity is $1 p>2 p>3 p$. This order is in reverse correlation with the mean sizes of $\mathrm{Cu}_{2} \mathrm{O}$ NP determined in Table 2. This result is in accordance with other studies on the biocidal activities of NP, where smaller particles inactivation of microorganisms was stronger due to higher total surface areas [42-44]. In our study, the highest inactivation effect (97\%) was achieved at $160 \mathrm{ppm}$ of $\mathrm{Cu}_{2} \mathrm{O}$ NP (Figure 4(d), sample $1 p 8$ ) after $24 \mathrm{~h}$ of treatment, while in another similar study, the same effect was observed at about $13 \mathrm{ppm}$ or $0.1 \mathrm{mM}$ of $\mathrm{Cu}_{2} \mathrm{O} \mathrm{NP}$ (sizes about $40 \mathrm{~nm}$ ) after $18 \mathrm{~h}$ of treatment [7]. The reason for the relatively low antibacterial efficiency in our study was the relatively high particle sizes of $\mathrm{Cu}_{2} \mathrm{O}$ NP $(240 \pm 21 \mathrm{~nm}$ in Table 2).

For easier evaluation of the effects of the postsynthesis incubation $\mathrm{pH}$ on $\mathrm{Cu}_{2} \mathrm{O} \mathrm{NP}$ antibacterial activities, the columns in Figures 4(a)-4(d) were regrouped and represented in another way (Figure 5). 


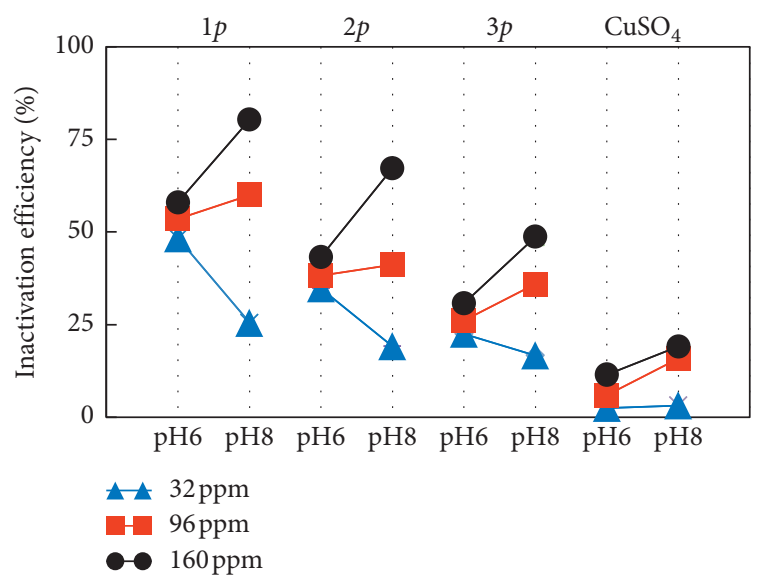

(a)

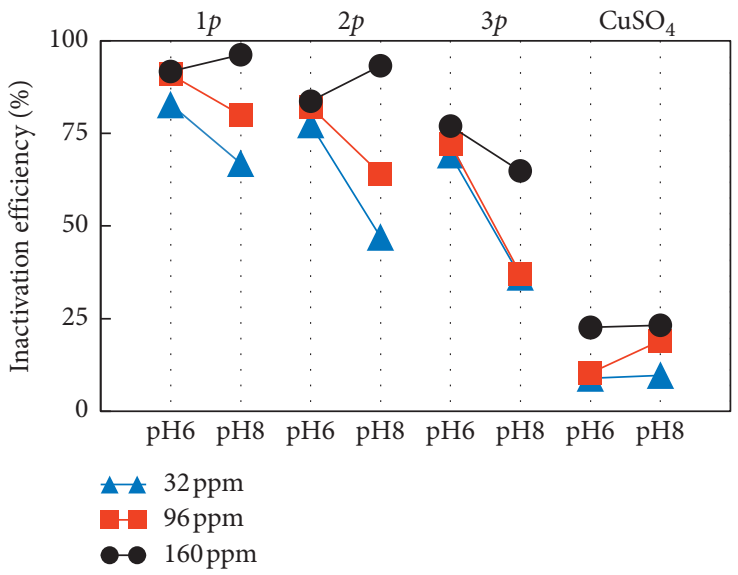

(b)

FIGURE 5: Interaction of incubation $\mathrm{pH}$ and copper dose on inactivation efficiency after treating E. coli for $1 \mathrm{~h}$ (a) and $24 \mathrm{~h}$ (b).

Figure 5 shows that there was an interaction effect of the $\mathrm{Cu}_{2} \mathrm{O} \mathrm{NP}$ incubation $\mathrm{pH}$ and their doses on E. coli inactivation efficiencies. After $1 \mathrm{~h}$ of treatment (Figure 5(a)) and at a low copper dose (32 ppm), the $\mathrm{Cu}_{2} \mathrm{O}$ NP6 had higher inactivation efficiencies than $\mathrm{Cu}_{2} \mathrm{O}$ NP8. However, increasing the copper dose to 96 and 160 ppm did not significantly enhance the antibacterial effect of $\mathrm{Cu}_{2} \mathrm{O}$ NP6 but noticeably improved that of $\mathrm{Cu}_{2} \mathrm{O}$ NP8. Eventually, the antibacterial effects of $\mathrm{Cu}_{2} \mathrm{O}$ NP8 were higher than those of $\mathrm{Cu}_{2} \mathrm{O}$ NP6 at 96 and $160 \mathrm{ppm}$. We suggest the following explanations for this interaction effect of copper dose and incubation $\mathrm{pH}$ on $\mathrm{Cu} 2 \mathrm{O} \mathrm{NP}$ antibacterial effect.

The surface of $\mathrm{Cu}_{2} \mathrm{O}$ NP6 was etched by the acidic disproportionation and became sharper with more edges and surfaces. Because the main antibacterial mechanism of $\mathrm{Cu}_{2} \mathrm{O}$ begins with direct contact with bacterial cell walls, the edges and surfaces on the $\mathrm{Cu}_{2} \mathrm{O}$ NP facilitate their penetration and interaction with the bacterial cell walls [7]. Another possible reason for the higher antibacterial effect of $\mathrm{Cu}_{2} \mathrm{O}$ NP6 is that their surface was protonated and had a positive charge, while $\mathrm{Cu}_{2} \mathrm{O} \mathrm{NP}$ in the alkaline medium absorbed hydroxide ions and had a negative charge [45]. At the same time, the $E$. coli cell surface has a small negative charge [46] and hence interacted better with $\mathrm{Cu}_{2} \mathrm{O}$ NP6. Therefore, $\mathrm{Cu}_{2} \mathrm{O}$ NP6 showed higher inactivation efficiencies, compared to $\mathrm{Cu}_{2} \mathrm{O}$ NP8 at $32 \mathrm{ppm}$.

However, increasing the dose of $\mathrm{Cu}_{2} \mathrm{O}$ NP6 from 32 to 96 and $160 \mathrm{ppm}$ did not significantly improve the antibacterial effect. This was possibly because a higher concentration of $\mathrm{Cu}_{2} \mathrm{O}$ NP6 resulted in a higher chance of their collisions and agglomeration. We suggest that the positive surface charge of $\mathrm{Cu}_{2} \mathrm{O}$ NP6 is smaller in magnitude, compared with the negative surface charge of $\mathrm{Cu}_{2} \mathrm{O}$ NP8; therefore, $\mathrm{Cu}_{2} \mathrm{O}$ NP6 are easier to agglomerate. The result of this agglomeration was a smaller amount of freely moving $\mathrm{Cu}_{2} \mathrm{O}$ particles that can get in contact with the bacterial cells. We suggest further measurement of the zeta potential of $\mathrm{Cu}_{2} \mathrm{O}$ NP6 and NP8 to confirm the hypothesis mentioned above.

A comparison of NP6 and NP8 in Figures 5(a) and 5 (b) at the same synthetic procedure and dose shows that
NP6 samples demonstrated higher increase in inactivation efficiencies when the treatment time increased from $1 \mathrm{~h}$ to $24 \mathrm{~h}$. For example, at the same $96 \mathrm{ppm}$ dose treatments (red lines in Figure 5), the inactivation efficiencies of NP6 were lower after $1 \mathrm{~h}$ and higher after $24 \mathrm{~h}$ than those of NP8. In other words, $\mathrm{Cu}_{2} \mathrm{O}$ "won" in the long-term antibacterial effects. For the case of $32 \mathrm{ppm}$ dose, the reason mentioned above for higher efficiencies of NP6 over NP8 can be applied. For the cases of 96 and $160 \mathrm{ppm}$ doses, we suggest that, during $24 \mathrm{~h}$ of shaking, the initial agglomerates of $\mathrm{Cu}_{2} \mathrm{O}$ NP6 gradually disintegrated and released more bactericidal $\mathrm{Cu}_{2} \mathrm{O}$ NP6. However, further experiments are required to test this hypothesis.

\section{Conclusions}

In this study, we investigated the effects of three different synthetic procedures on the size distribution of $\mathrm{Cu}_{2} \mathrm{O} N P$ prepared by reducing $\mathrm{CuSO}_{4}$ with glucose in an alkaline medium in the presence of PVA capping agent. The onestep procedure at high reaction rate yielded $\mathrm{Cu}_{2} \mathrm{O}$ NP with the lowest sizes, while a fast-then-slow procedure yielded more uniform particles in size. The synthesis at a low temperature with subsequent Ostwald ripening at a high temperature produced the largest $\mathrm{Cu}_{2} \mathrm{O}$ NP. The different procedures also yielded NP with different shapes. Moreover, postsynthesis incubation of $\mathrm{Cu}_{2} \mathrm{O} N P$ in acidic or basic solutions also affects the size distribution as well as the antibacterial activity of these NP. Incubating $\mathrm{Cu}_{2} \mathrm{O} N P$ in an acidic solution resulted in an etching effect on the $\mathrm{Cu}_{2} \mathrm{O} \mathrm{NP}$ size and size distribution. Moreover, acidic incubation of $\mathrm{Cu}_{2} \mathrm{O}$ NP increased their antibacterial activity, possibly due to the formation of sharp edges and positive charges on the $\mathrm{Cu}_{2} \mathrm{O}$ surface. However, increasing the doses of the acid-incubated $\mathrm{Cu}_{2} \mathrm{O}$ NP increased the antibacterial effect not significantly, possibly due to agglomeration of the $\mathrm{Cu}_{2} \mathrm{O}$ NP. Further investigations are required to clarify the unsolved hypotheses suggested in this study. 


\section{Data Availability}

The data used to support the findings of this study are available from the corresponding author upon request.

\section{Conflicts of Interest}

The authors declare that there are no conflicts of interest regarding the publication of this paper.

\section{Acknowledgments}

The authors gratefully thank the Ho Chi Minh City University of Technology and Education for financial and facility support in completing this research. The authors thank Ms. Tran Thi Tuong Vi and Ms. Tran Thi Ngoc Han for their helpful technical assistance.

\section{References}

[1] F. C. Tenover, "Development and spread of bacterial resistance to antimicrobial agents: an overview," Clinical Infectious Diseases, vol. 33, no. s3, pp. S108-S115, 2001.

[2] D. Campoccia, L. Montanaro, and C. R. Arciola, "A review of the biomaterials technologies for infection-resistant surfaces," Biomaterials, vol. 34, no. 34, pp. 8533-8554, 2013.

[3] F. Paladini, M. Pollini, A. Sannino, and L. Ambrosio, "Metalbased antibacterial substrates for biomedical applications," Biomacromolecules, vol. 16, no. 7, pp. 1873-1885, 2015.

[4] A. Syafiuddin, Salmiati, M. R. Salim, A. Beng Hong Kueh, T. Hadibarata, and H. Nur, "A review of silver nanoparticles: research trends, global consumption, synthesis, properties, and future challenges," Journal of the Chinese Chemical Society, vol. 64, no. 7, pp. 732-756, 2017.

[5] S. Mallick, S. Sharma, M. Banerjee, S. S. Ghosh, A. Chattopadhyay, and A. Paul, "Iodine-stabilized $\mathrm{Cu}$ nanoparticle chitosan composite for antibacterial applications," ACS Applied Materials \& Interfaces, vol. 4, no. 3, pp. 1313-1323, 2012.

[6] H. L. Karlsson, P. Cronholm, J. Gustafsson, and L. Möller, "Copper oxide nanoparticles are highly toxic: a comparison between metal oxide nanoparticles and carbon nanotubes," Chemical Research in Toxicology, vol. 21, no. 9, pp. 1726-1732, 2008.

[7] S. Meghana, P. Kabra, S. Chakraborty, and N. Padmavathy, "Understanding the pathway of antibacterial activity of copper oxide nanoparticles," RSC Advances, vol. 5, no. 16, pp. 12293-12299, 2015.

[8] H.-J. Park, T. T. M. Nguyen, J. Yoon, and C. Lee, "Role of reactive oxygen species in Escherichia coli Inactivation by cupric ion," Environmental Science \& Technology, vol. 46, no. 20, pp. 11299-11304, 2012.

[9] A. P. Ingle, N. Duran, and M. Rai, "Bioactivity, mechanism of action, and cytotoxicity of copper-based nanoparticles: a review," Applied Microbiology and Biotechnology, vol. 98, no. 3, pp. 1001-1009, 2014.

[10] H. Pang, F. Gao, and Q. Lu, "Morphology effect on antibacterial activity of cuprous oxide," Chemical Communications, no. 9, pp. 1076-1078, 2009.

[11] K. Sunada, M. Minoshima, and K. Hashimoto, "Highly efficient antiviral and antibacterial activities of solid-state cuprous compounds," Journal of Hazardous Materials, vol. 235236, pp. 265-270, 2012.
[12] B. D. Du, D. T. B. Ngoc, N. D. Thang, L. N. A. Tuan, B. D. Thach, and N. Q. Hien, "Synthesis and in vitro antifungal efficiency of alginate-stabilized $\mathrm{Cu}_{2} \mathrm{O}-\mathrm{Cu}$ nanoparticles against Neoscytalidium dimidiatum causing brown spot disease on dragon fruit plants (Hylocereus undatus)," Vietnam Journal of Chemistry, vol. 57, no. 3, pp. 318-323, 2019.

[13] K. Giannousi, G. Sarafidis, S. Mourdikoudis, A. Pantazaki, and C. Dendrinou-Samara, "Selective synthesis of $\mathrm{Cu}_{2} \mathrm{O}$ and $\mathrm{Cu} / \mathrm{Cu}_{2} \mathrm{O}$ NPs: antifungal activity to yeast Saccharomyces cerevisiae and DNA interaction," Inorganic Chemistry, vol. 53, no. 18, pp. 9657-9666, 2014.

[14] J.-K. Lung, J.-C. Huang, D.-C. Tien et al., "Preparation of gold nanoparticles by arc discharge in water," Journal of Alloys and Compounds, vol. 434-435, pp. 655-658, 2007.

[15] S. Rahmah and F. Kurniawan, "Electrochemical methods for manufacturing silver nanoparticles," in Proceedings of the 5th SEA-DR (South East Asia Development Research) International Conference 2017 (SEADRIC 2017), Banjarmasin, Indonesia, May 2017.

[16] J. S. Gabriel, V. A. M. Gonzaga, A. L. Poli, and C. C. Schmitt, "Photochemical synthesis of silver nanoparticles on chitosans/ montmorillonite nanocomposite films and antibacterial activity," Carbohydrate Polymers, vol. 171, pp. 202-210, 2017.

[17] S. Ganguly, P. Das, M. Bose et al., "Sonochemical green reduction to prepare Ag nanoparticles decorated graphene sheets for catalytic performance and antibacterial application," Ultrasonics Sonochemistry, vol. 39, pp. 577-588, 2017.

[18] A. P. Reverberi, N. T. Kuznetsov, V. P. Meshalkin, M. Salerno, and B. Fabiano, "Systematical analysis of chemical methods in metal nanoparticles synthesis," Theoretical Foundations of Chemical Engineering, vol. 50, no. 1, pp. 59-66, 2016.

[19] M. B. Gawande, A. Goswami, F.-X. Felpin et al., "Cu and Cubased nanoparticles: synthesis and applications in catalysis," Chemical Reviews, vol. 116, no. 6, pp. 3722-3811, 2016.

[20] X. Han, F. Liao, Y. Zhang, Z. Yuan, H. Chen, and C. Xu, "Rapid and template-free synthesis of $\mathrm{Cu}_{2} \mathrm{O}$ truncated octahedra using glucose as green reducing agent," Materials Letters, vol. 210, pp. 31-34, 2018.

[21] C. M. Phan and H. M. Nguyen, "Role of capping agent in wet synthesis of nanoparticles," The Journal of Physical Chemistry A, vol. 121, no. 17, pp. 3213-3219, 2017.

[22] V. K. LaMer and R. H. Dinegar, "Theory, production and mechanism of formation of monodispersed hydrosols," Journal of the American Chemical Society, vol. 72, no. 11, pp. 4847-4854, 1950.

[23] E. C. Vreeland, J. Watt, G. B. Schober et al., "Enhanced nanoparticle size control by extending LaMer's mechanism," Chemistry of Materials, vol. 27, no. 17, pp. 6059-6066, 2015.

[24] T. Sugimoto, "Preparation of monodispersed colloidal particles," Advances in Colloid and Interface Science, vol. 28, pp. 65-108, 1987.

[25] L. Zhang, Q. Li, H. Xue, and H. Pang, "Fabrication of $\mathrm{Cu}_{2} \mathrm{O}$ based materials for lithium-ion batteries," ChemSusChem, vol. 11, no. 10, pp. 1581-1599, 2018.

[26] L. S. B. Upadhyay and N. Kumar, "Green synthesis of copper nanoparticle using glucose and polyvinylpyrrolidone (PVP)," Inorganic and Nano-Metal Chemistry, vol. 47, no. 10, pp. 1436-1440, 2017.

[27] P. Moeck, Y. Waseda, E. Matsubara, and K. Shinoda, "Yoshio waseda, eiichiro matsubara, kozo shinoda, X-ray diffraction crystallography," Crystal Research and Technology, vol. 47, no. 11, pp. 1210-1211, 2012.

[28] C. Suryanarayana and M. Grant Norton, X-Ray Diffraction: A Practical Approach, Springer, Berlin, Germany, 2013. 
[29] A. Hitchins, Bacteriological Analytical Manual, Food and Drug Administration, Washington, DC, USA, 1998.

[30] S. Li, Y. Chen, L. Huang, and D. Pan, "Large-scale synthesis of well-dispersed copper nanowires in an electric pressure cooker and their application in transparent and conductive networks," Inorganic Chemistry, vol. 53, no. 9, pp. 4440-4444, 2014.

[31] V. Andal and G. Buvaneswari, "Effect of reducing agents in the conversion of $\mathrm{Cu}_{2} \mathrm{O}$ nanocolloid to $\mathrm{Cu}$ nanocolloid," Engineering Science and Technology, an International Journal, vol. 20, no. 1, pp. 340-344, 2017.

[32] A. K. Sasmal, S. Dutta, and T. Pal, "A ternary $\mathrm{Cu}_{2} \mathrm{O}-\mathrm{Cu}-\mathrm{CuO}$ nanocomposite: a catalyst with intriguing activity," Dalton Transactions, vol. 45, no. 7, pp. 3139-3150, 2016.

[33] S. Thoka, A.-T. Lee, and M. H. Huang, "Scalable synthesis of size-tunable small $\mathrm{Cu}_{2} \mathrm{O}$ nanocubes and octahedra for facetdependent optical characterization and pseudomorphic conversion to Cu nanocrystals," ACS Sustainable Chemistry \& Engineering, vol. 7, no. 12, pp. 10467-10476, 2019.

[34] S. Mourdikoudis, R. M. Pallares, and N. T. K. Thanh, "Characterization techniques for nanoparticles: comparison and complementarity upon studying nanoparticle properties," Nanoscale, vol. 10, no. 27, pp. 12871-12934, 2018.

[35] T. Sugimoto and F. Shiba, "Spontaneous nucleation of monodisperse silver halide particles from homogeneous gelatin solution II: silver bromide," Colloids and Surfaces A: Physicochemical and Engineering Aspects, vol. 164, no. 2-3, pp. 205-215, 2000.

[36] G. Hua, L. Zhang, G. Fei, and M. Fang, "Enhanced catalytic activity induced by defects in mesoporous ceria nanotubes," Journal of Materials Chemistry, vol. 22, no. 14, pp. 6851-6855, 2012.

[37] J. Canivet, M. Vandichel, and D. Farrusseng, "Origin of highly active metal-organic framework catalysts: defects? Defects!" Dalton Transactions, vol. 45, no. 10, pp. 4090-4099, 2016.

[38] Y. Xia, Y. Xiong, B. Lim, and S. E. Skrabalak, "Shape-controlled synthesis of metal nanocrystals: simple chemistry meets complex physics?" Angewandte Chemie International Edition, vol. 48, no. 1, pp. 60-103, 2009.

[39] V. V. Kumar and S. P. Anthony, "Antimicrobial studies of metal and metal oxide nanoparticles," in Surface Chemistry of Nanobiomaterials, pp. 265-300, Elsevier, Amsterdam, Netherlands, 2016.

[40] M. Hans, A. Erbe, S. Mathews, Y. Chen, M. Solioz, and F. Mücklich, "Role of copper oxides in contact killing of bacteria,” Langmuir, vol. 29, no. 52, pp. 16160-16166, 2013.

[41] L. K. Limbach, P. Wick, P. Manser, R. N. Grass, A. Bruinink, and W. J. Stark, "Exposure of engineered nanoparticles to human lung epithelial cells: influence of chemical composition and catalytic activity on oxidative stress," Environmental Science \& Technology, vol. 41, no. 11, pp. 4158-4163, 2007.

[42] S. AlYahya, B. J. Rani, G. Ravi et al., "Size dependent magnetic and antibacterial properties of solvothermally synthesized cuprous oxide $\left(\mathrm{Cu}_{2} \mathrm{O}\right)$ nanocubes," Journal of Materials Science: Materials in Electronics, vol. 29, no. 20, pp. 17622-17629, 2018.

[43] T. D. Majumdar, M. Singh, M. Thapa, M. Dutta, A. Mukherjee, and C. K. Ghosh, "Size-dependent antibacterial activity of copper nanoparticles against Xanthomonas oryzae pv. oryzae-a synthetic and mechanistic approach," Colloid and Interface Science Communications, vol. 32, p. 100190, 2019.

[44] B. She, X. Wan, J. Tang, Y. Deng, X. Zhou, and C. Xiao, "Sizeand morphology-dependent antibacterial properties of cuprous oxide nanoparticle and their synergistic antibacterial effect," Science of Advanced Materials, vol. 8, no. 5, pp. 1074-1078, 2016.

[45] M. D. Susman, R. Popovitz-Biro, A. Vaskevich, and I. Rubinstein, "pH-Dependent galvanic replacement of supported and colloidal $\mathrm{Cu}_{2} \mathrm{O}$ nanocrystals with gold and palladium," Small, vol. 11, no. 32, pp. 3942-3953, 2015.

[46] J. Li and L. McLandsborough, "The effects of the surface charge and hydrophobicity of Escherichia coli on its adhesion to beef muscle," International Journal of Food Microbiology, vol. 53, no. 2-3, pp. 185-193, 1999. 